\title{
REVIEW
}

\section{Humic substances - compounds of still unknown structure: applications in agriculture, industry, environment, and biomedicine}

\author{
Eladia M. Peña-Méndez ${ }^{1}$, Josef Havel $^{2}$, Jiří Patočka ${ }^{3}$ \\ ${ }^{1}$ Department of Analytical Chemistry, Nutrition and Food Science, Faculty of Chemistry, University of La \\ Laguna, Spain \\ ${ }^{2}$ Department of Analytical Chemistry, Faculty of Science, Masaryk University, Brno, Czech Republic \\ ${ }^{3}$ Department of Toxicology, Military Medical Academy, Hradec Králové and Department of Radiology, \\ Faculty of Health and Social Studies, University of South Bohemia, České Budějovice, Czech Republic
}

Received $20^{\text {th }}$ September 2004.

Revised $20^{\text {th }}$ October 2004.

Published online $22^{\text {nd }}$ November 2004

\begin{abstract}
Summary
Humic substances as part of humus-soil organic matter - are compounds arising from the physical, chemical and microbiological transformation (humification) of biomolecules. They are important because they constitute the most ubiquitous source of non-living organic material that nature knows. Approximately $80 \%$ of the total carbon in terrestrial media and $60 \%$ of the carbon dissolved in aquatic media are made up of humic substances. Humic substances have important roles in soil fertility, and are considered to have primal relevance for the stabilization of soil aggregates. They can be divided into three components according to their solubility: humic acids, fulvic acids and humin. Humic acids are the most explored group of humic substances. Beyond their relevance for life these substances have industrial applications in the development of absorbents to be used at the sources of metal-poisoning. Being natural substances, their purification process is cheaper than the synthesis of any other sorbent and, moreover, due to their high operability, they absorb more than the absorbents used to date, such as active charcoals or clays. The specific properties of humic acid products enable their application in industry, agriculture, environmental and biomedicine.
\end{abstract}

Keywords: humification - humin - humic acids - fulvic acids

Eladia M. Peña-Méndez, Department of Analytical Chemistry, Nutrition and Food Science, Faculty of Chemistry, University of La Laguna, 38071-La Laguna, Spain

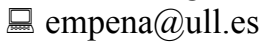

\section{INTRODUCTION}

Humic substances (HS) are the most widely-spread natural complexing ligands occurring in nature. The presence of $\mathrm{HS}$ in soils have also been detected, even in the Antarctic continent where the humification process under Antarctic conditions is very specific and different from the other 
continents (Gajdošová et al. 2001, Pacheco and Havel 2002, Gajdošová et al. 2003). They make up the bulk of organic matter, because they represent most of the organic materials of soil, peat, lignites, brown coals, sewage, natural waters and their sediments. Humic substances can be divided into three components: fulvic acids (FAs), humic acids (HAs) and humin. One of the most important parts of HS is HAs. Humic acids and FAs represent alkali-soluble humus fragments, humin represents the insoluble residue. Because of their molecular structure, they provide numerous benefits to crop production. They help break up clay and compacted soils, assist in transferring micronutrients from the soil to the plant, enhance water retention, increase seed germination rates and penetration, and stimulate the development of microflora populations in soils (Senesi et al. 1991).

The remarkable properties of humic acids have attracted the attention of many investigators. The results over the years have brought new knowledge on their structure and physicochemical properties and pointed to the use of these interesting natural compounds in many practical applications. The aim of this article is to review the current state of knowledge and to present current applications in agriculture, industry, the environment, and biomedicine (see, e.g. Ziechmann 1994).

\section{HISTORY}

The term "humus" originates from the Romans, when it was familiarly used to signify the entire soil. Later the term was used to denominate soil organic matter and compost or for different parts of this organic matter, as well as for complexes created by chemical agent treatments to a wide palette of organic substances. The principal definition of humus, as decomposed organic matter, originates from 1761 (Stevenson 1982).

The first relevant study of the origin and chemical nature of HS was worked out by Sprengel (1839). His comprehensive study on the acidic nature of HAs is thought to be his most important benefit to humus chemistry. Research on the chemical properties of HS was extended by the Swedish researcher Berzelius, whose main contribution was the isolation of two light-yellowcoloured HS from mineral water and slimy mud rich in iron oxides (Berzelius 1839).

Enormous advances have been made during the last decade thanks to modern physicochemical methods. Nevertheless, the structural chemistry of lignin and HS did not advance so fast as the chemistry of animal-originated biopolymers.

\section{WHERE DO HUMIC SUBSTANCES COME FROM?}

Although the formation process of HS has been studied hard and for a long time, their formation is still the subject of long-standing and continued research. Some theories have lasted for years; for example, the 'sugar-amine condensation' theory, the 'lignin' theory or the 'polyphenol' theory. A review of such theories can be found in a monograph of Davies and Ghabbour 1999. Nowadays, most investigators suppose that humic substances originated in lignin (Oglesby et al. 1967).

Polyphenols come mostly from lignin during its biodegradation, and probably play a key role in the formation process. Polyphenols are also regarded as the main agents in the formation of humic substances from some plants that do not contain much lignin and/or from non-lignin containing plants. Polyphenols can be considered as humic acid precursors. They themselves possess enough reactive sites to permit further transformations, for example some condensation reactions.

The humic substances system is created. by the association of various components present in the humification process, such as amino acids, lignins, pectins or carbohydrates, through intermolecular forces (donor-acceptor, ionic, hydrophilic, and hydrophobic) It is evident that the mechanisms of the formation of humic substances can be slightly different, depending on geographical, climatic, physical and biological circumstances, respectively. These compounds can be formed in several ways, and the role of lignin is important in the majority of these processes (Burdon 2001, Davies et al. 2001). Burdon (2001) proposed that humic organic matter consists mainly of a mixture of plant and microbial constituents plus the same constituents in various stages of decomposition (i.e. plant/microbial mixtures of carbohydrates, proteins, lipids and partially degraded lignins, tannins, melanins, etc.).

\section{CHARACTERIZATION OF HUMIC SUBSTANCES}

As already pointed out, all the humic substances can be divided into components according to their solubility in different media (Fig. 1). Humic acids and FAs represent alkali-soluble humus fragments; HAs are commonly extracted using diluted alkali and precipitated with an acid, and so are separated from the soluble FAs. Humin represents the insoluble residue (Thorn 1996).

From a geological point of view, humic substances are chemical intermediates between plants and fossils. The chemical nature of soils, 
sludge and sediments can subsequently, continually and selectively vary via the conversion and degradation of organic matter (Ziechman 1993). Extinct vegetation represents the main source of organic matter transforming to humic substances in the environment. Humification is a continuous historical process, and soil humus is a dynamic system of both chemically active and passive components (Gonzalez et al. 2003). The amount of organic carbon in the Earth in the form of humic substances exceeds that which makes up living organisms (Engel and Macko 1993).

Humic acids, one of the most important components of HS, help break up clay and compacted soils, assist in transferring micronutrients from soil to plants, enhance water retention, increase seed germination rates, and stimulate the development of microflora populations in soils. Humic acids also slow down water evaporation from soils. This is especially important in soils where clay is present at low concentration or not at all, in arid areas, and in sandy soils without the capability to hold water. Humic acids provide also sites for microflora to colonize. Bacteria secrete enzymes which act as catalysts, liberating calcium and phosphorous from insoluble calcium phosphate, and iron and phosphorous from insoluble iron phosphate. The chemical structure of HAs is very complicated and depends on their source.

The elemental composition of different FAs and HAs shows that the major elements in their composition are $\mathrm{C}, \mathrm{H}, \mathrm{O}, \mathrm{N}$, and $\mathrm{S}$. These major elements are always present regardless their origin and country or continent (Gajdošová et al. 2001, Tan 2003, Kurková et al. 2004). Moreover, besides elemental composition, group composition is used to characterize HS as it gives information about the chemistry and structural properties of HS (Purdue 1988, Tan et al. 2000). Fulvic acids contain more functional groups of an acidic nature, particulary - $\mathrm{COOH}$. The total acidities of fulvic acids (900$1400 \mathrm{mmol} / 100 \mathrm{~g}$ ) are considerably higher than for humic acids (400-870mmol/100g). Another important difference is that while the oxygen in fulvic acids is largely in known functional groups $(-\mathrm{COOH},-\mathrm{OH},-\mathrm{C}=\mathrm{O})$, with a high oxygen content, the acidity and degree of polymerisation all change systematically with increasing molecular weight. The proportion of oxygen in humic acids seems to occur as a structural component of the nucleus.

The formation of aggregates within solutions of humic acids was studied by capillary electrophoresis for the first time by Fetsch et al. (1998a, 1998b). Humic acids (HAs) aggregation has also been studied in aqueous solution by high performance size exclusion chromatography (Peuravuori and Pihlaja 1997), light scattering (Manning et al. 2000), vapor pressure osmometry
(VPO) (Marinsky et al. 1990), ultrafiltration (Aiken and Malcom (1987), conductometry and spectrophotometry in combination with factor analysis (Peña-Méndez et al. 2004). HAs consist of a mixture of molecules with much lower molecular weight than proposed before in the literature. HAs components are low molecular weight compounds but they aggregate step by step to give higher molecular weight aggregates and supramolecules of higher molecular weight. Hosse and Wilkinson (2001), using fluorescence correlation spectroscopy observed that the aggregation of HAs is due to the formation of dimers and trimers at low $\mathrm{pH}$.

The characterization of complex mixtures of FAs and HAs is considered to be one of the most important items in HS research nowadays. Thanks to the development of analytical techniques and computer technologies, great efforts have been made to elucidate the molecular structures of FAs and HAs. From the work of Stevenson (1982), Buffle et al. (1977) to more recent models of Shulten (2002, 2003), Kujawinski et al. (2002a, $2002 \mathrm{~b}$ ) and Stenson et al. (2002, 2003), several molecular structures describing the structure of humic acids have been proposed. For a long time, it has been suggested using different analytical techniques that HAs are high molecular weight compounds. However, five years ago, we proved by $\mathrm{CE}$ that HAs are low molecular weight compounds. This was announced for the first time at the $9^{\text {th }}$ International Meeting of the IHSS, Adelaide Australia, September 20-25, 1998, IHSS, Atlanta (Havel et al. 2001) and in a subsequent publication. Mass spectra of HAs (Fig. 4) obtained by LDI-TOF MS shows the presence of low molecular weight molecules from low $\mathrm{m} / \mathrm{z}$ values to higher. The analysis of the mass spectra obtained for different HAs showed that several $\mathrm{m} / \mathrm{z}$ values are the same for all the HAs, suggesting that some compounds are the same and that they are present in HAs from very different origins and sources. The latest results from mass spectrometry (MS) combined with other analytical techniques have confirmed our previous results. As for fulvic acids, several thousand compounds have been identified, and are considered to be mostly derived from lignin (Kujawinski et al. 2002a, Stenson et al. 2003).

The chemical formulas of individual fulvic acids have been determined (Stenson et al. 2003). In the case of HAs, interesting results have been achieved recently applying Electrospray Ionization (ESI) (Kujawinski et al. 2002a, Brown and Rice 2002, Kujawinski et al. 2002b, Stenson et al. 2002, Stenson et al. 2003) coupled with Fourier Transform ICR mass spectrometry (FT-ICR) and Laser Desorption/Ionization time of flight (LDITOF) (Pokorná et al. 1999, Havel et al. 1999, Gajdošová et al. 2000, Gajdošová et al. 2003). Based on the latest experimental results obtained by LDI-TOF MS and also on the base of the 
isotopic patterns observed for compounds present in HAs (Fig. 4), Pacheco and Havel (2004) have suggested the latest empirical formula for HAs; the results from their model are in a good agreement with those obtained by ESI (Kujawinski et al. 2002a, Brown and Rice 2002, Kujawinski et al. 2002b, Stenson et al. 2002, Stenson et al. 2003).

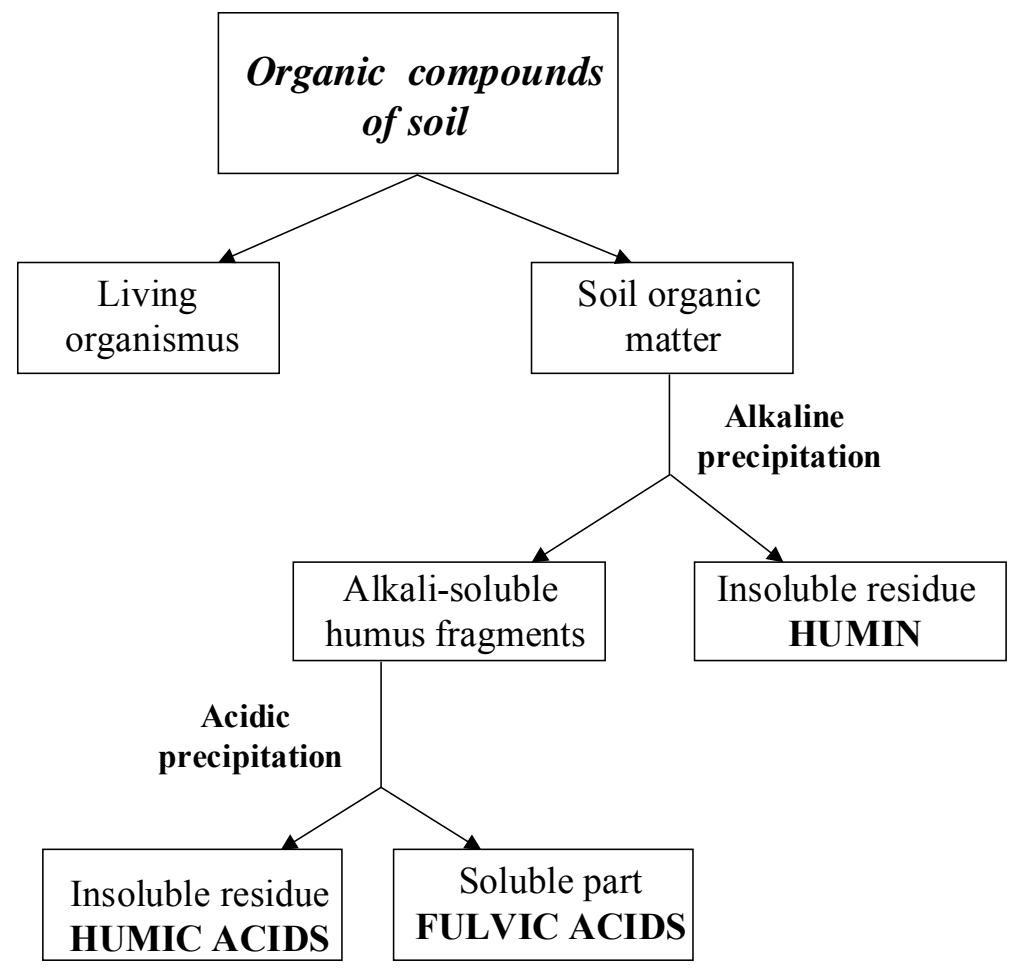

Fig. 1. Scheme of division of humic substances in dependence of their solubility.

\section{APPLICATIONS OF HUMIC SUBSTANCES}

Humus represents one of the greatest carbon reservoirs on Earth. So far, industrial applications of humus and humus-derived products are rare. On the contrary, the usage of coal was more abundant and essentially, it constituted the basis of the chemical industry in the second half of the 19th century and the first half of the 20th century. Petroleum was also an application and it was regarded as the main raw material for the chemical industry of the $20^{\text {th }}$ century. Nowadays, applications of HS can be divided into four main categories: agriculture, industry, environment and biomedicine.

\section{Agriculture applications}

HS play an important role from the agronomical point of view. They influence significantly the quality and productivity of the soil. In addition to the improvement of the soil's physical properties and moisture conditions mentioned above, HS also show a high base exchange capacity, which is important for soil fertility (Lotosh 1991, Zhang and He 2004).

Currently, humic materials are used as additives in fertilizers (García et al. 1994, Madejon et al. 2001, Albiach et al. 2001, Kerek et al. 2003, Arancon et al 2004). Different salts of humic substances, such as calcium humate, were used to increase soil fertility (e.g. Buckau et al. 2000). The fertilizing effect of sodium humate on plant leaves has been described. Ammonium humate was also found to have a significant growth-stimulating effect (Lotosh 1991). The characteristics of and applications for humic acids extracted from different compost have also been studied (Ceppi et al. 1999, Madejon et al. 2001, Arancon et al 2004).

The growth-promoting effect of humic substances has been observed by many investigators and humates are often part of different preparations for growth-improvement of plants. Productivity of soil is increased by different ways in the presence of humic materials. The indirect effects of humic substances are very important as they integrate iron to the chelates and make it available to plants. Another role of humic substances lies in the enhancement of the quality of 
soils when they are very poor in organic matter. Recent research shows that humic acid can be used as farm animal feed thanks to its growth-promoting effect (e.g. Kocabagli et al. 2002).

\section{Industrial applications}

Humus and humus-containing materials have been used in large-scale building, for instance, as additives to control the setting rate of concrete. Humic materials found use also in the preparation of leather. Initially, they were used as a leather dye, later on as an agent for tanning leather and, finally, as an ingredient of a solution to finish leather.

The woodworking industry is another field where HS have been applied. They were used to prepare a "natural indigo" to dye wood veneer. In addition to this use, humic materials appeared to be suitable agents as a component of water-soluble stains for wood furniture.

In the ceramic industry, humic substances were employed mainly as additives to enhance the mechanical strength of unprocessed ceramics, to improve the casting properties of ceramics (Waksman 1938), to color clay tiles and among many other uses they were also applied in the preparation of earthenware.
Furthermore, humic materials have found application in the production of plastics, especially as dyes for coloring Nylon 6 or PVC plastics, hardeners of polyurethane foams or as plasticizer ingredients for PVC (Majakova and Proskurjakov 1972).

Humic materials found numerous applications in the paper industry too. They are included in different manufacturing procedures, for example in the production of electricity conducting paper sheets or in the manufacture of high tensile strength paper, and also in the recycling of paper. Other industrial applications can be mentioned: as an ion exchanger, as a source of synthetic hydrocarbons and fuel oils (Duncan et al. 1981), in foodprocessing or to enhance the extraction of uranium from its ores (Schmeide et al. 2000). Humic substances have a large capacity to retain transition metals, forming metalorganic complexes, which cause these metals to be more or less available for plants which include then them into the food chain.

Interesting possibilities are the manufacture of humic substances from the waste processing industry. Results showed that the conversion of cellulose into humic acids is clearly underway in the production of recycled liquid packaging board (LPB) bales (Koivula and Hanninen 1999)

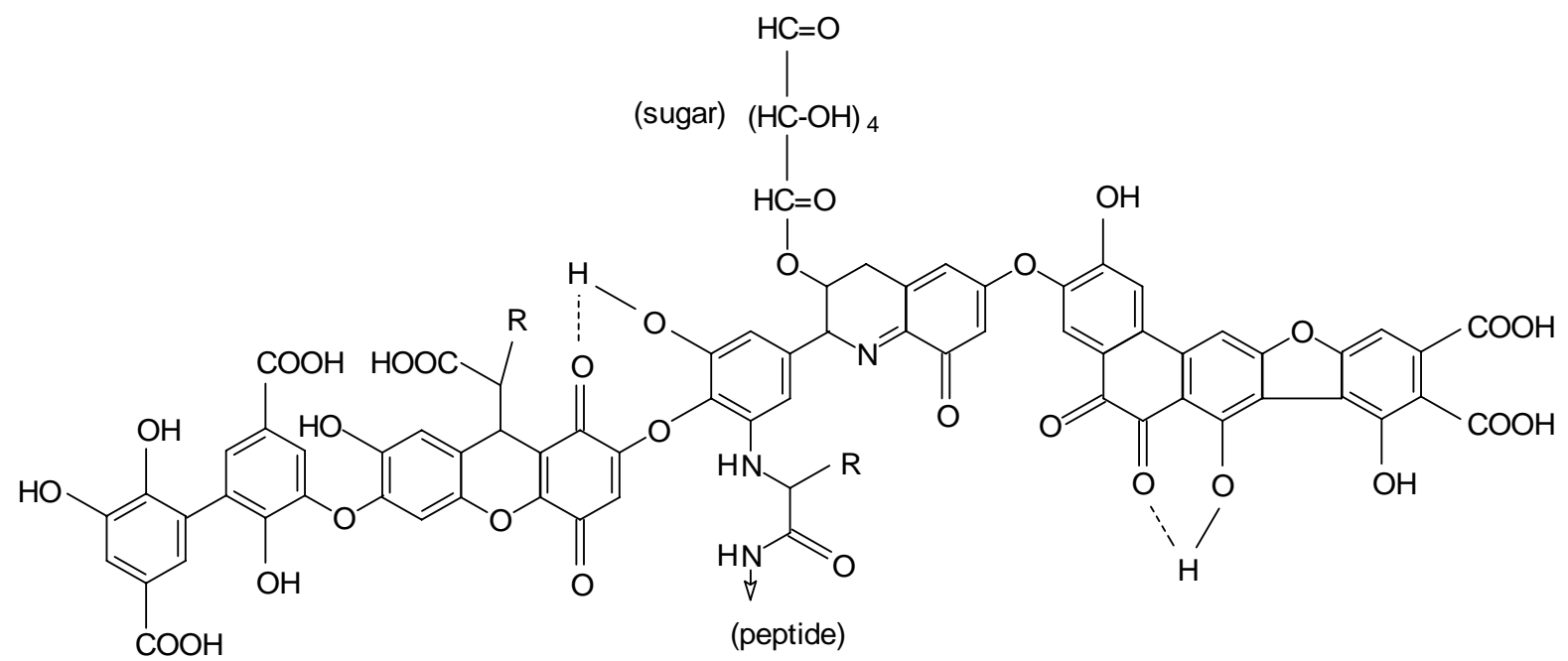

Fig. 2. Model structure of humic acid according to Stevenson (1982); R can be alkyl, aryl or aralkyl.

\section{ENVIRONMENTAL APPLICATIONS}

Natural organic colloids (humic and fulvic acids) are important because they form water-soluble complexes with many metals including radionuclides (Lubal et al. 1998, Lubal et al. 2000, Pacheco and Havel 2001, Ghabbour et al. 2001). These organics may therefore be important as radionuclide transport agents through the environment. It is known that the presence of humic substances in natural waters can influence the uptake of radionuclides by natural solids and thus their migration to surface and ground waters (Bondietti 1982, Samanidou et al. 1991). The main task of humic substances in environmental chemistry is to remove toxic metals, anthropogenic organic chemicals and other pollutants from water. Ion-exchange materials based on calcium humate were found suitable for the removal of such heavy metals as iron, nickel, mercury, cadmium and 
copper from water and also to remove radioactive elements from water discharges from nuclear power plants. Their selective binding capabilities are also exploited for the destruction of munitions and chemical warfare agents (Ghabbour and Davies 1999). Humus-based filters have been developed for sewage purification, with many applications. The filters are useful to clean chromate smelter wastewater, to remove oil and dyes from wastewaters and aquatic systems (Versraete and Devliegher 1997), to filter urban and industrial<smiles>CC(CC(=O)O)C(CCO)C(=O)Cc1c(CCC(=O)C(O)C(=O)O)c(O)c2c(C(=O)O)c(C(=O)O)c(C(=O)O)c(O)c2c1C(=O)O</smiles>

Fig. 3. Model structure of fulvic acid according to Buffle et al. (1977)

wastewaters, to remove pesticides from sewage and to remove phenol from water.

Humus-containing materials have been also utilized for sorbing gases, e.g. the removal of waste gases from an animal-carcass rendering plant. Slightly modified humates can be applied to remove hydrogen sulfide and mercaptans from municipal gas supplies, and sulfur dioxide from stack gases (Green and Manahan 1981).

Different groups of compounds such as herbicides, fungicides, insecticides, nematicides, dioxins and also some pharmaceutical products like estrogenic compounds were determined as possible environmental endocrine disruptors. Thanks to their ability to adsorb organic pollutants from the environment, humic substances were found to be useful to remove those contaminants from water, soil and sewage sludges (Shin et al. 1999, Lofredo et al. 2000). The complex nature of the interaction between HS and xenobiotics and their influence in the environmental quality (water, soil, and atmosphere) has been studied by different authors. The study of the acido-basic and complexation properties of HAs with several inorganic and organic compounds has attracted increased attention due to their influence on many aspects of soil and water quality, and industrial processes. Pacheco et al. (2003) found that some inorganic and/or organic pollutants were strongly complexed (bound) only with some of the HAs components. As a consequence of such interaction quite stable entities of the supramolecular kind were formed.

The interactions between humic materials and microorganisms have been intensively studied for the past 30 years. It was found that fermenting bacteria could reduce humic substances. This fact has significant implications for the autecology of anaerobic bacteria in soils and sediments. The cumulative production of acetate during this process seems to be energetically advantageous for fermenting bacteria (Benz et al. 1998). Utilization of humics as the energy supply for specific bacteria, fungi and higher microorganisms was studied by many investigators (Bhardwaj and Gaur 1971) but it was noted that they can not exploit humic materials as a food source.

\section{BIOMEDICAL APPLICATIONS}

Humic substances produced on a commercial scale are used in veterinary and human medicine. Several studies of the medicinal properties of humic materials have been reported (Mund-Hoym 1981, Brzozowski et al. 1994). It was found that humic acids administered prophylactically to rats decreased significantly the extension of gastric damage induced by ethanol. TPP administered to rats with experimental gastric and duodenal ulcers significantly accelerated the healing process (Brzozowski et al. 1994)

Pflug and Ziechman (1982) reported that humic acids are able to interact with the bacterium Micrococcus luteus. In this case humic materials protected the organism against cell-wall disruption by the enzyme lysozyme. Thiel et al. (1981), who found that preincubation of cell cultures with ammonium humate avoided infection by the herpes virus, noted the function of humic substances as protectors of the organism.

In the last decade there has been an increasing interest in the employment of humic materials in medicine and biology. The possibility of soil humus extract with amino acid complexes and vitamin $\mathrm{B}$ analogues being a candidate as a base of 
cosmetic and pharmaceutical products has been studied. The main reason for the increasing attention devoted to humic acids can be explain by their antiviral, profibrinolytic, anti-inflammatory and estrogenic activities (Yamada et al. 1998). The potential of humic substances to form chelate

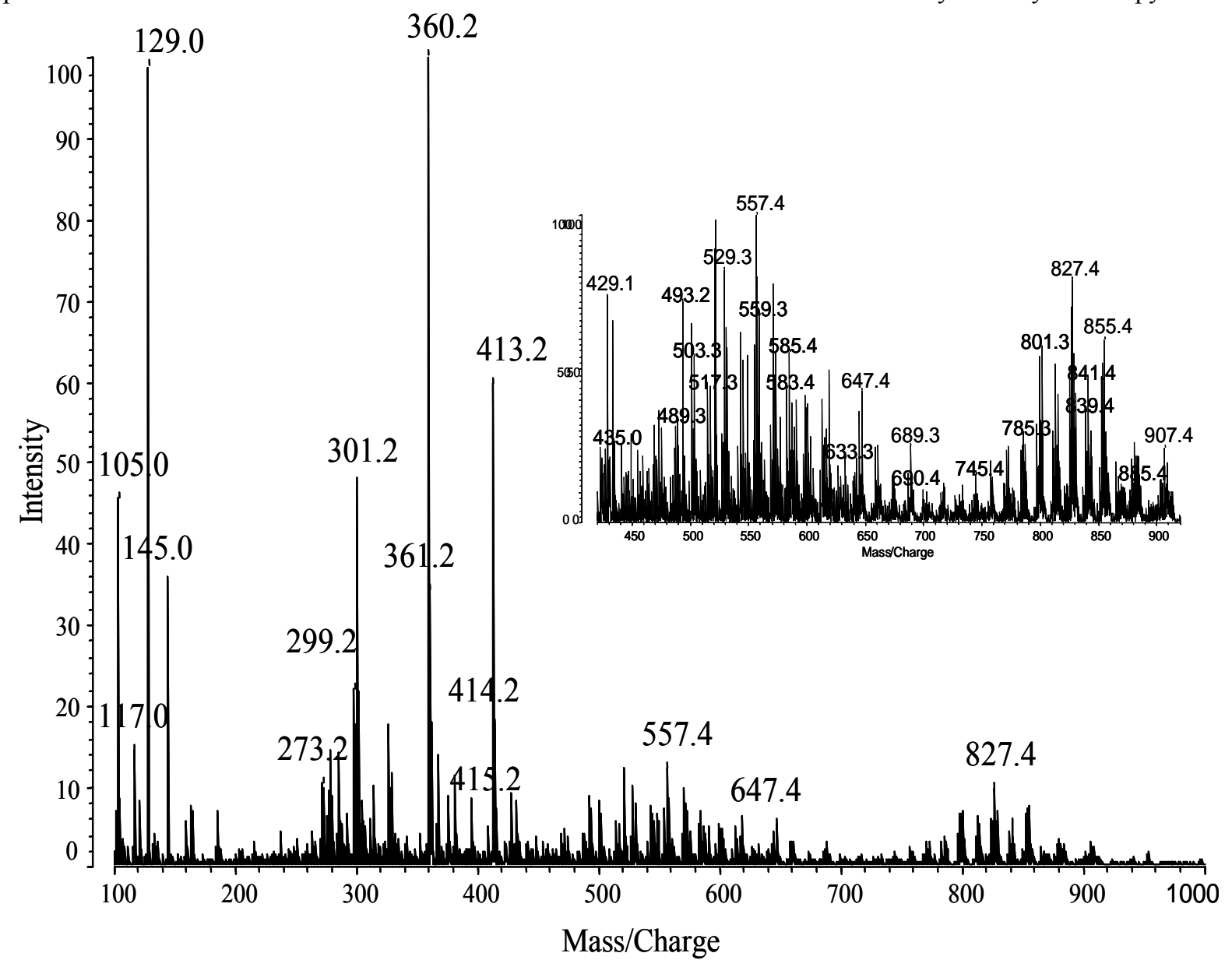

Fig. 4. LDI TOF MS mass spectra of HAs soil (IHSS).

balneotherapy (Gadzhieva et al. 1991, Hampl et al. 1994).

Antibacterial (Ansorg 1978, Skliar et al. 1998) and antiviral (Klöcking and Sprossig 1972, Thiel et al. 1977 1981, Schiller et al. 1979, Klicking 1991, Klöcking et al. 2002) properties of humic substances represent new possibilities for their medical application.

Of great interest is that hospital studies show that difficult viral respiratory illnesses common in children are readily resolved with fulvic acid dietary supplementation. Fulvic acid is a humic extract common to rich organic humus soil and also certain ancient plant deposits. Many medical studies show that humic substances, especially fulvic acids, have the power to protect against cancer and related cancer-causing viruses. Studies often show reversal of deadly cancers and tumors using special humic substance therapies (Schneider et al. 1996, van Rensburg et al. 2002, Joone et al. 2003). complexes with heavy metals (such as cadmium) enable them to be used for the elimination of heavy metals from living organisms (Klöcking 1992). Humic materials in aquatic systems and water sediments have been observed to be closely connected with efficacy of hydrotherapy and 
were a relatively low scale, usage of coal was more abundant and was the basis of the chemical industry in the second half of the 19th century and in the first half of the 20th century. Petroleum was also applied and it is considered as the main raw material for the chemical industry of the $20^{\text {th }}$ century (Ghabbour and Davies 2001).

Now it is time for new applications of humic substances in less traditional arenas, mainly in biomedicine (Laub 1999, Laub 2003a, Laub b, Ghosal, 2003).

\section{CONCLUSIONS}

Humic substances are group of organic compounds formed by the association of high-molecular-mass substances from microbiological, vegetative and animal origin. They are organic macromolecules with multiple properties and high structural complexity. They exist abundantly in soil, natural water and various terrestrial and aquatic environments. The humic substances group can be divided into three components based on their solubility: fulvic acids, humic acids, and humin. Fulvic acids and humic acids represent alkalisoluble humus fragments and humin represents the insoluble residue. As for the structure, it is still not known, although there has been a breakthrough by Havel's research group using CE and MALDI-TOF MS indicating that HAs should not be considered as high molecular weight compounds Regardless of the still unknown structure of humic substances and the great efforts to elucidate, it is known that their major functional groups include carboxylic, phenolic, carbonyl, hydroxyl, amine, amide and aliphatic moieties, among others. Due to this polyfunctionality, humic substances are one of the most powerful chelating agents among natural organic substances. The zwitterionic character of humic substances allows the interaction of anions with positively charged groups of humics and cations with negative charged groups of these substances. The unique chemical properties of humic substance products enable their application in industry, agriculture, environmental and biomedicine. In HAs there are compounds with potentially important pharmaceutical or medicinal properties and the search for or and investigation of these compounds is of great importance for pharmaceutical and biomedical applications.

\section{ACKNOWLEDGEMENT}

This work was supported by Ministry of Education, Youth and Sport, MSM 143100007 and MSM 143100011, Czech Republic. E.M. Peña-Méndez would like to thank the Canarian Government (Spain) for financial support.

\section{REFERENCES}

Aiken G.R. and Malcom R.L.: Molecular weight of aquatic fulvic acids by vapor pressure osmometry. Geochim. Cosmochim. Acta 51:2177-2184, 1987.

Albiach R., Canet R., Pomares F., Ingelmo F.: Organic matter components, aggregate stability and biological activity in a horticultural soil fertilized with different rates of two sewage sludges during ten years. Biores. Technol. 77:109-114, 2001.

Ansorg R. and Rochus W.: Studies on the antimicrobial effect of natural and synthetic humic acids. Arzeimittelforschung 28:21952198, 1978.

Arancon N.Q., Edwards C.A., Bierman P., Welch C., Metzger J.D.: Influences of vermicomposts on field strawberries: 1. Effects on growth and yields. Bioresource Techn. 93:145-153, 2004.

Benz M., Schink B., Brune A.: Humic acid reduction by Propionibacterium freudenreichii and other fermenting bacteria. Appl. Environ. Microbiol. 64:4507-4512, 1998.

Berzelius J.J.: Lehrbuch der Chemie. Wöhler, Dresden and Leipzig 1839.

Bhardwaj K.K. andGaur A.C.: Studies on the growth stimulating action of humic acid on bacteria. Zentralbl. Bakteriol. Parasitenkd. Infektionskr. Hyg. 126:694-699, 1971.

Buffle J., Greter F.L., Haerdi W.: Measurement of complexation properties of humic and fulvic acids in natural waters with lead and copper ion-selective electrodes. Anal. Chem. 49:216222, 1977.

Buckau G., Hooker P., Moulin V., et al.: Versatile components of plants, soils and water In: Ghabbour E.A. and Davies G. (eds): Humic Substances, RSC, Cambridge 2000.

Burdon J.: Are the traditional concepts of the structures of humic substances realistic? Soil Sci. 166:752-769, 2001.

Bondietti E.: Environmental migration of longlived radionuclides. IAEA, Vienna 1982.

Brzozowski T., Dembinski A., Konturek S.: Influence of Tolpa Peat Preparation on gastroprotection and on gastric and duodenal ulcers. Acta Pol. Pharm. 51:103-107, 1994.

Brown T. L. and Rice J.A.: Effect of experimental parameters on the ESI FT-ICR mass spectrum of fulvic acid. Anal. Chem. 72:384-390, 2000.

Davies G. and Ghabbour E.A. (eds.): Humic substances, structures, properties and uses. The RSC, Cambridge 1999.

Davies G., Ghabbour E.A., Steelink C.: Humic acids: Marvelous products of soil chemistry. J. Chem. Educ. 78:1609-1614, 2001.

Duncan D.A., Bodle W.W., Banejerd D.P.: Energy from biomass and waste. $5^{\text {th }}$ Symposium, 
Papers: Institute of Gas Technology, Chicago, 1981, pp. 917.

Engel M.H. and Macko S.A. (eds.): Organic Geochemistry, Plenum Press, New York and London 1993.

Fetsch D., Albrecht-Gary A.M., Peña-Méndez E.M., Havel J.: Capillary zone electrophoresis of humic acids. Scripta Fac. Sci. 1997, pp. 2737.

Fetsch D., Hradilová M., Peña-Méndez E.M., Havel J.: Capillary zone electrophoresis study of humic substances aggregation. J. Chromatogr. A. 817:313-323, 1998a.

Fetsch D., Fetsch M., Peña-Méndez E.M., Havel J.: Humic acids capillary zone electrophoresis adsorption on capillary walls, separation in metal ion supplemented buffer and the fingerprints. Electrophoresis 19:2465-2473, 1998b.

Fetsch D. and Havel J.: Capillary zone electrophoresis for the separation and characterization of humic acids. J. Chromatogr. A. 802:189-202, 1998c.

Gadzhieva N.Z., Tsoi E.P., Turovskaia S.I., Ammosova I.M.: The antibacterial activity of a humic preparation made from the therapeutic peat mud of the Dzalal Abad deposit in Kirgizia. Naucn. Dokl. Vyss. Skoly Biol. Nauki 10:109-113, 1991.

Gajdošová D., Pokorná L., Kotz A., Havel J.: Mass spectrometry and capillary electrophoresis analysis of coal-derived humic acids produced from oxyhumolite. A comparative study. In: Humic substances. Versatile components of plants, soils and water. Ghabbour E.A. and G. Davies (eds.):RSC, Cambridge 2000, pp. 289-298.

Gajdošová D., Pokorná L., Láska S., Prošek P., Havel J.: Are there humic acids in Antarctica? In Ghabbour E.A. and Davies G. (eds): Humic Substances. Structures, Models and Functions. RSC, Cambridge 2001, pp. 121-131.

Gajdošová D., Novotná K., Prosek P., Havel J.: Separation and characterization of humic acids from Antarctica by capillary electrophoresis and matrix-assisted laser desorption ionization timeof-flight mass spectrometry inclusion complexes of humic acids with cyclodextrins. J. Chromatogr. A. 1014:117-127, 2003.

Garcia D., Cegarra J., Roig A., Abad M.: Effects of the extraction temperature on the characteristics of a humic fertilizer obtained from lignite. Biores. Technol. 47:103-106, 1994.

Ghabbour E.A., Davies G., Ghali N.K., Mulligan M.D.: The effect of temperature on tight metal binding by peat and soil derived solid humic acids. Canad. J. Soil. Sci. 81:331336, 2001.

Ghabbour E.A. and Davies G. (eds.): Humic substances: structures, models and functions.
Based on proceedings, RSC, Cambridge 2001, p. 401.

Gonzalez M.G., M.E. Conti, R.M. Palma, N.M. Arrigo: Dynamics of humic components and microbial activity under no-tillage or reduced tillage, as compared with native pasture (Pampa Argentina). Biol. Fert. Soils 39: 135138, 2003.

Green J.B. and S.E. Manahan: Absorption of sulphur dioxide by sodium humates. Fuel 60 : 488-494, 1981.

Havel J. and D. Fetsch: Humic substances. Capillary zone electrophoresis. In Wilson I. (ed.): Encyclopedia of Separation Science. Academic Press Ltd., London 2000.

Havel J., D. Fetsch, E.M. Peña-Méndez, P. Lubal, J. Havliš: Recent developments in humic acid characterization. Acidobasic and complexation properties, separation and reliable fingerprints by capillary electrophoresis and MALDI-TOF mass spectrometry. Swift R.S. and K.M. Spark (eds.). Understanding and Managing Organic Matter in Soils, Sediments, and Waters. $9^{\text {th }}$ International Meeting of the IHSS, Adelaide 1998, pp. 20-25, IHSS, Atlanta 2001, pp. 7782.

Hosse M. and K.J. Wilkinson: Determination of electrophoretic mobilities and hydrodynamic radii of three humic substances as a function of $\mathrm{pH}$ and ionic strength. Environ. Sci. Technol. 35: 4301-4306, 2001

Ho K.J., T.K. Liu, T.S. Huang, F.J. Lu: Humic acid mediates iron release from ferritin and promotes lipid peroxidation in vitro: a possible mechanism for humic acid-induced cytotoxicity. Arch. Toxicol. 77: 100-109, 2003.

Joone G.K., J. Dekker, C.E. van Rensburg: Investigation of the immunostimulatory properties of oxihumate. Z. Naturforsch. 58: 263-267, 2003.

Kiss G., E. Tombácz, B. Varga, R. Alsberg, L. Persson: Estimation of the average molecular weight of humic-like substances isolated from fine atmospheric aerosol. Chemosphere 37: 3783-3794, 2003.

Klöcking R. and M. Sprossig: Antiviral properties of humic acids. Experientia 28: 607-608, 1972.

Klöcking R.: Interaction of humic acids and humicacid-like polymers with herpes simplex virus type 1. Humanic Substances in the Aquatic and Terrestrial Environment, Berlin 1991, pp. 408412.

Klöcking R.: Humic substances in the global environment and implications in human health. Monopoli 1992, p. 129.

Klöcking R., B. Helbig, G. Schotz, M. Schacke, P. Wutzler: Anti-HSV-1 activity of synthetic humic acid-like polymers derived from p-diphenolic starting compounds. Antivir. Chem. Chemother. 13: 241-249, 2002. 
Kocabagli N., M. Alp, N. Acar, R. Kahraman: The effects of dietary humate supplementation on broiler growth and carcass yield. Poult. Sci. 81: 227-230, 2002.

Koivula N. and K. Hanninen: Biodeterioration of cardboard-based liquid containers collected for fibre reuse. Chemosphere 38: 1873-1887, 1999.

Kujawinski E.B., P.G. Hatcher, M.A. Freitas: Highresolution fourier transform ion cyclotron resonance mass spectrometry of humic and fulvic acids: improvements and comparisons. Anal. Chem. 74: 413-419, 2002a.

Kujawinski E.B., M.A. Freitas, X. Zang et al.: The application of electrospray ionization mass spectrometry to the structural characterization of natural organic matter. Org. Geochem. 33: 171-180, 2002b.

Kurková M., Z. Klika, Ch. Kliková, J. Havel: Humic acids from oxidised coal I. Elemental composition, titration curves, heavy metals in HA symplex, nuclear magnetic resonance spectra of HAs and infrared spectroscopy. Chemosphere 54: 1237-1245, 2004.

Laub R.J.: Process for preparing synthetic soil-extract materials and medicaments based thereon. US Patent 5,945,446, 1999.

Laub R.J.: Synthetic soil-extract materials and medicaments for herpes viruses based thereon. US Patent 6,524,566, 2003a.

Laub R.J.: Synthetic soil-extract materials and medicaments for human immunodeficiency viruses based thereon. US Patent 6,534,049, 2003b.

Ghosal S.: Delivery system for pharmaceutical, nutritional and cosmetic ingredients. US Patent 6,558,712, 2003.

Loffredo E., M. Pezzuto, N. Senesi: Humic Substances: Versatile Components of Plants, Soils and Water. E.A. Ghabbour and G. Davies (eds.): RSC, Cambridge 2000.

Lotosh T.D.: Experimental bases and prospects for the use of humic acid preparations from peat in medicine and agricultural production. (In Russian) Naucn. Dokl. Vyss. Skoly. Biol. Nauki 10: 99-103, 1991.

Lubal P., D. Široký, D. Fetsch, J. Havel: The acidobasic and complexation properties of humic acids. Study of complexation of Czech humic acids with metal ions. Talanta 47: 401-412, 1998.

Lubal P., D. Fetsch, D. Šroký et al.: Potentiometric and spectroscopic study of uranyl complexation with humic acids. Talanta 51: 977-991, 2000.

Madejón E., R. López, J.M. Murillo, F. Cabrera: Agricultural use of three (sugar-beet) vinasse composts: effect on crops and chemical properties of a Cambisol soil in the Guadalquivir river valley (SW Spain). Agric. Ecosyst. Environm. 84: 55-65, 2001.
Majakova E.F. and V.A. Proskurjakov: Proc. $4^{\text {th }}$ International Peat Congress, Ontaniemi 1972 p. 235.

Manning T.J., T. Bennett, D. Milton: Aggregation studies of humic acid using multiangle laser light scattering. Sci. Total Environ. 257: 171176, 2000.

Marinsky J.A. and M.M. Reddy: Vapor-pressure osmometric study of the molecular weight and aggregation tendency of a reference-soil fulvic acid. Anal. Chim. Acta 232: 123-130, 1990.

Mine K., R.A. Drijber, R.E. Gaussoin: Labile soil organic matter as a potential nitrogen source in golf greens. Soil Biol. Biochem. 35: 16431649, 2003.

Mund-Hoym W.D.: The effect of salhumin baths on rheumatic and traumatic joint diseases. Med. Welt. 32: 1378-1381, 1981.

Oglesby R.T., R.F. Christman, C.H. Driver: The biotransformation of lignin to humus facts and postulates. Adv. Appl. Microbiol. 9: 171-84, 1967.

Pacheco M.L. and J. Havel: Capillary zone electrophoretic study of uranium(VI) complexation with humic acids. J. Radioanal. Nucl. Chem. 248: 565-570, 2001.

Pacheco M.L. and J. Havel: Capillary zone electrophoresis of humic acids from American continent. Electrophoresis 23: 268-277, 2002.

Pacheco M.L., E.M. Peña-Méndez, J. Havel: Supramolecular interactions of humic acids with organic and inorganic xenobiotics studied by capillary electrophoresis. Chemosphere 51: 95-108, 2003.

Pacheco M.L. and J. Havel: New results from capillary electrophoresis and MALDI TOF MS studies of humic acids interactions with various compounds and xenobiotics. In Ghabbour E.A. and G. Davies (eds): Humic Substances: Molecular Details and Applications in Land and Water Conservation. Taylor and Francis Inc., New York 2005, in print.

Peña-Méndez E.M., D. Fetsch, J. Havel: Aggregation of humic acids in aqueous solution vapor pressure osmometric, conductivity, spectrophotometric study. Anal. Chim. Acta 2004, in print.

Peuravuori J. and K. Pihlaja: Molecular size distribution and spectroscopic properties of aquatic humic substances. Anal. Chim. Acta 337: 133-149, 1997.

Pflug W. and W. Ziechman: Humic acids and the disruption of bacterial cell walls by lysozyme. Soil Bio. Biochem. 14: 165-166, 1982.

Pokorná L., D. Gajdošová, J. Havel: Characterization of humic acids by capillary zone electrophoresis and matrix assisted laser desorption ionisation time of flight mass spectropmetry. In Ghabbour E.A. and G. Davies (eds.): Understanding Humic Substances: 
Advanced Methods, Properties and Applications. RSC, Cambridge 1999.

Pokorná L., M.L. Pacheco, J. Havel: Highly reproducible capillary zone electrophoresis of humic acids in cyclodextrines or oligosaccharides modified background electrolytes. J. Chromatogr. A. 895: 345-350, 2000.

Pokorná L., D. Gajdošová, S. Mikeska, J. Havel: Analysis and characterization of a "standard" coal derived humic acid, humic substances. In Ghabbour E.A. and G. Davies (eds.): Versatile components of plants, soils and water. RSC, Cambridge 2000, pp. 299-329.

Pokorná L., D. Gajdošová, S. Mikeska, P. Homoláč, J. Havel: The stability of humic acids in alkaline media. In: Humic Substances. Structures, Models and Functions. Ghabbour E.A. and G. Davies (eds.): RSC, Cambridge 2001, pp 133-149.

Purdue E.M.: Measurements of binding site concentrations in humic substances. In Kramer J.R. and H.E. Allen (eds): Metal Speciation Theory, Analysis, and Applications. Lewis Publ., Chelsea 1998, pp. 135-154.

Samanidou V., I. Papadoyannis, G. Vasilikiotis: Mobilization of heavy-metals from river sediments of Northern Greece, by humic substances. J. Environm. Sci. Health A26: 1055-1068, 1991.

Schmeide K., S. Pompe, M. Bubner, K.H. Heise, G. Bernhard, H. Nitsche: Uranium(VI) sorption onto phyllite and selected minerals in the presence of humic acid. Radiochim. Acta 88: 723-728, 2000.

Schulten H.-R.: Models of humic structures: Association of humic acids and organic matter in soils and water. In Clapp C.E, M.H.B. Hayes, N. Senesi, P.R. Bloom, P.M. Jardine (eds.): Humic Substances and Chemical Contaminants: Proc. Workshop and Symp. Int. Humic Substances Soc., Soil Sci. Soc. Am., Am. Soc. Agronomy, Anaheim 1997, pp. 26-27. Soil Sci. Soc. Am., Inc., Madison 2001, pp. 73-87.

Schulten H.-R.: New approaches to the molecular structure and properties of soil organic matter: Humic-, xenobiotic-, biological-, and mineralbounds:. In Violante A., P.M. Huang, J.-M. Bolag, L. Gianfreda (eds.): Soil MineralOrganic Matter-Microorganisms Interactions and Ecosystem Health. Dynamics, Mobility and Trasformations of Pollutans and Nutrients. Development in Soil Science 28A, Elsevier, Amsterdam 2000, pp. 351-381.

Senesi N., T.M. Miano, M.R. Provenzano, G. Brunetti: Characterization, differentiation, and classification of humic substances by fluorescence spectroscopy. Soil Sci. 152: 259$271,1991$.
Šenkýř J., D. Ročáková, D. Fetsch, J. Havel: The acidobasic and complexation properties of humic acids. Study of humic acids complexation with cadmium and lead (II) by pulse anodic strippping voltametry. Tox. Environ. Chem. 33: 1-15, 1998.

Schiller F., R. Klöcking, P. Wutzler, I. Farber: Results of an oriented clinical trial of ammonium humate for the local treatment of herpesvirus hominis infections. Dermatol. Monatsschr. 165: 505-509, 1979.

Schneider J., R. Weis, C. Manner et al.: Inhibition of HIV-1 in cell culture by synthetic humate analogues derived from hydroquinone: mechanism of inhibition. Virology 218: 389395, 1996.

Shin D., Y. Chung, Y. Choi et al.: Assessment of disinfection by-products in drinking water in Korea. J. Expo. Anal. Environ. Epidemiol. 9: 192-199, 1999.

Skliar T.V., A.V. Krysenko, V.G. Gavriliuk, A.I. Vinnikov: A comparison of the developmental characteristics of Neisseria gonorrhoeae and Staphylococcus aureus cultures on nutrient media of different compositions. Mikrobiol. Z. 60: 25-30, 1998.

Sprengel K.: Die Bodenkunde oder die Lehre vom Boden. Müller, Leipzig 1839.

Stenson A.C., W.M. Landing, A.G. Marshall, W.T. Copper: Ionization and fragmentation of humic substances in electrospray ionization Fourier transform-ion cyclotron resonance mass spectrometry. Anal. Chem. 74: 4397-4409, 2002.

Stenson A.C., A.G. Marshall, W.T. Copper: Exact masses and chemical formulas of individual suwannee river fulvic acids from ultrahigh resolution ESI FT-ICR mass spectra. Anal. Chem. 75: 1275-1284, 2003.

Stevenson F.J.: Humus chemistry genesis, composition, reactions. Willey Interscience, New York 1982.

Tan K.H., R.A. Leonard, L.E. Asmussen, J.C. Lobartine, A.R. Gingle: Composition of humic acids extracted under air and nitrogen atmosphere. Comm. Soil Sci. Plant. Anal. 21: 1999-2016, 2002.

Tan K.H.: Chemical composition of humic matter. In: Humic Matter in Soil and the Environment. Principles and Controversies. Marcel and Dekker, New York 2003.

Thiel K.D., R. Klöcking, H. Schweizer, M. Sprossig: In vitro studies of the antiviral activity of ammonium humate against herpes simplex virus type 1 and type 2 . German Zentralbl. Bakteriol. 239: 304-321, 1977.

Thiel K.D., B. Helbig, R. Klöcking, P. Wutzler, M. Sprossig, H. Schweizer: Comparison of the in vitro activities of ammonium humate and of enzymically oxidized chlorogenic and caffeic 
acids against type 1 and type 2 human herpes virus. Pharmazie 36: 50-53, 1981.

Thorn K.A., W.S. Goldenberg, S.J. Youngerand, E.J. Weber: Humic and fulvic acids: isolation, structure, and environmental role. In Gaffney J.S., N. A. Marley, S. B. Clark (eds.): ACS Symposium Series 651, 1996, p. 299.

Van Rensburg C.E., J. Dekker, R. Weis, T.L. Smith, J. van Rensburg, J. Schneider: Investigation of the anti-HIV properties of oxihumate. Chemotherapy 48: 138-143, 2002.

Verstraete W. and W. Devliegher: Formation of non-bioavailable organic residues in soil: perspectives for site remediation. Biodegradation 7: 471-485, 1997.
Waksman S.A.: Humus: origin, chemical composition, and importance in nature. Williams and Wilkins Co., Baltimore 1938.

Yamada E., T. Ozaki, M. Kimura: Determination and behavior of humic substances as precursors of trihalomethane in environmental water. Anal. Sci. 14: 327-332, 1998.

Zhang M. and Z. He: Long-term changes in organic carbon and nutrients of an Ultisol under rice cropping in southeast China. Geoderma 118: 167-179, 2004.

Ziechmann W.: Humic Substances. George August Universität Göttingen, Bibliographischer Institut. Wissenschaftsverlag, Mannheim 1994. 